\title{
ENZYMIC ACTION OF ACROSOMAL PREPARATIONS ON THE RABBIT OVUM IN VITRO
}

\author{
P. N. SRIVASTAVA, G. E. ADAMS AND E. F. HARTREE \\ A.R.C. Unit of Reproductive Physiology and Biochemistry, University of Cambridge*
}

(Received 11th November 1964)

\begin{abstract}
Summary. Cell-free enzyme preparations consisting of lipoglycoprotein were obtained from acrosomes of ram, bull and rabbit spermatozoa. The ram and bull preparations showed proteolytic and hyaluronidase activities. Preparations from the three species brought about dispersal of the cumulus oophorus and corona radiata of newly ovulated rabbit eggs. In some cases the zona pellucida was also removed. Iodoacetate and a polyanionic hyaluronidase inhibitor each reduced the denuding activity of the ram preparation and to a lesser extent of the bull preparation. Heating to $100^{\circ} \mathrm{C}$ also reduced the activity of the ram and bull preparations. It is concluded that proteolytic enzymes in spermatozoa contribute to the denudation of rabbit eggs and probably facilitate penetration of the zona pellucida.
\end{abstract}

\section{INTRODUCTION}

The cumulus oophorus of rabbit eggs is dispersed in vitro by suspensions of rabbit spermatozoa (Pincus, 1930; Yamane, 1930). According to McLean \& Rowlands (1942) this action is due to the enzyme hyaluronidase which is released from the spermatozoa. The corona radiata, on the other hand, is not dispersed either by sperm or by hyaluronidase (Swyer, 1947; Chang, 1950; Braden, 1952; Dickmann, 1962). The role of hyaluronidase in the fertilization process has been reviewed by Austin (1961) and by Mann (1964).

The feasibility of using cationic detergents to detach acrosomes from spermatozoa was demonstrated by Hathaway \& Hartree (1963). Using the cationic detergent Hyamine 2389 (methyl dodecyl benzyl trimethyl ammonium chloride and methyl dodecyl xylylene bis trimethyl ammonium chloride), Hartree \& Srivastava (1965) developed a method for obtaining suspensions of ram and bull acrosomes which are virtually free from sperm. These acrosomal materials are lipoglycoprotein complexes. In the present paper we describe the effects of such preparations upon newly ovulated rabbit eggs with particular reference to denudation.

\section{MATERIALS AND METHODS}

Acrosomal lipoglycoproteins of ram, bull and rabbit spermatozoa were obtained by Method B of Hartree \& Srivastava (1965) except that removal of lipid from the complexes by means of chloroform and methanol was omitted. After the acrosomal suspensions, obtained by treating spermatozoa with Hyamine

* Postal address: Animal Research Station, 307 Huntingdon Road, Cambridge, England.

C 
2389, had been diluted with an equal volume of ethanol the resulting precipitate was suspended in calcium-free Ringer solution (Mann, 1946) and dialysed overnight at $4^{\circ} \mathrm{C}$ against the same solution. The protein content of the product was determined by the method of Lowry, Rosebrough, Farr \& Randall (1951) and adjusted, by addition of Ringer solution, to $6 \mathrm{mg} / \mathrm{ml}$.

Human plasma $\mathrm{Ba}-\alpha_{2}$ glycoprotein (Schmid \& Burgi, 1961) was supplied by Dr Schmid, and a guinea-pig serum glycoprotein (fraction 1 of Simkin, Skinner \& Seshadri, 1964) by Dr Simkin. These two glycoproteins will be referred to as $\mathrm{A}$ and $\mathrm{B}$ respectively. Luteinizing hormone (Lutormone) was obtained from Burroughs Wellcome, hyaluronic acid (human umbilical cord) from Light \& Co, Hyamine 2389 from British Drug Houses, hyaluronidase (Hyalase, ovine) from Bengers Laboratories Ltd, and $p$-chloromercuriphenylsulphonic acid from Sigma Chemical Co. Sialic acid ( $\mathcal{N}$-acetylneuraminic acid) was prepared from boar semen gel using the method described by Zilliken, Braun \& Györgyi (1956). Hyaluronidase inhibitor 53DK (Parkes, Rogers \& Spensley, 1954) was provided by Dr Rogers.

\section{Estimation of Hyamine 2389}

Since this anionic detergent was used to detach acrosomes from spermatozoa it was necessary to determine residual Hyamine in lipoglycoprotein solutions in order that the necessary control experiments could be set up. The method takes advantage of the fact that the extinction of Hyamine is much higher at $275 \mathrm{~m} \mu$ than at $295 \mathrm{m \mu}$. A suitable volume of lipoglycoprotein solution is diluted to $5 \mathrm{ml}$ with Ringer solution, treated with $5 \mathrm{ml}$ of $10 \%(\mathrm{w} / \mathrm{v})$ perchloric acid, heated $10 \mathrm{~min}$ at $80^{\circ} \mathrm{C}$, cooled and shaken with $5 \mathrm{ml}$ of $n$-butanol. The Hyamine passes quantitatively into the butanol layer. This layer is clarified by centrifuging and its extinctions $(E)$ at 275 and $295 \mathrm{~m} \mu$ are determined using $10 \mathrm{~mm}$ silica cuvettes. The reference cuvette contains $n$-butanol. The concentration of Hyamine in the $5 \mathrm{ml}$ of diluted lipoglycoprotein solution is 0.072 $\left(E_{275}-E_{295}\right) \%(\mathrm{w} / \mathrm{v})$.

\section{Collection and treatment of eggs}

Rabbits (sixteen in all) were injected intravenously with 25 i.u. of luteinizing hormone to induce ovulation. About $13 \mathrm{hr}$ later, at autopsy, the fallopian tubes were excised and flushed with $0.9 \% \mathrm{NaCl}$ (saline). At recovery, the eggs were invariably found embedded in a cumulus clot from which individual eggs were dissected out (Pl. 1, Fig. 1). Each egg, still surrounded by cumulus, was placed in a small tube with $0.5 \mathrm{ml}$ of saline followed by the test substance(s) dissolved in $0.5 \mathrm{ml}$ of Ringer solution. The stoppered tubes were incubated at $37^{\circ} \mathrm{C}$ for $24 \mathrm{hr}$ and the eggs were examined microscopically $(25 \times$ and $100 \times)$ at $6 \mathrm{hr}$ and $24 \mathrm{hr}$.

\section{Enzyme assays}

Hyaluronidase activity was determined, as turbidity reducing units (TRU), by the method of Tolksdorf (1954). Proteolytic activity was measured by incubating solutions of lipoglycoprotein either alone (autoproteolysis) or with three times recrystallized egg albumen. Activity was measured at $37^{\circ} \mathrm{C}$ in 
water, Ringer solution, or phosphate buffer, $\mathrm{pH} 6 \cdot 8$. Incubations were carried out in open test tubes or under nitrogen in Thunberg tubes. The concentration of amino groups (as glycine) was estimated periodically by the method of Yemm \& Cocking (1955).

\section{RESULTS}

DENUDATION OF RABBIT OVA BY AGROSOMAL LIPOGLYCOPROTEINS

The effects of the lipoglycoproteins are summarized in Table 1. To describe the extent of denudation of eggs the following arbitrary scale is used.

Cumulus still present

Cumulus removed, thick layer of corona cells present 1

Thin layer of corona cells

Complete removal of corona

Zona pellucida removed

We shall refer to state 3 as denudation.

TABLE 1

EFFEGTS OF ACROSOMAL LIPOGLYGOPROTEINS (LGP) FROM RAM AND BULL SPERMATOZOA UPON RECENTLY OVULATED RABBIT EGGS. INFLUENCE OF PROTEIN-BINDING REAGENTS AND OF A HYALURONIDASE INHIBITOR (53DK)

\begin{tabular}{l|c|c}
\hline \multicolumn{1}{c|}{ Incubation medium } & $\begin{array}{c}\text { No. of } \\
\text { experiments }\end{array}$ & Effect* \\
\hline Ringer-saline & 5 & 0 \\
Ringer-saline +0.01\% Hyamine & 3 & 0 \\
Ram LGP & 5 & $3-4$ \\
Ram LGP (15 min at $\left.100^{\circ} \mathrm{G}\right)$ & 2 & 1 \\
Ram LGP +0.01 M-iodoacetate & 2 & $1-3$ \\
Ram LGP +0.01 M-p-chloromercuri- & 2 & 3 \\
phenylsulphonate & 2 & 1 \\
Ram LGP +53 DK (0.1 mg/ml) & 4 & $3-4$ \\
Bull LGP & 2 & 1 \\
Bull LGP (15 min at $\left.100^{\circ} \mathrm{G}\right)$ & 2 & 3 \\
Bull LGP +0.01 M-iodoacetate & 2 & 4 \\
Bull LGP +0.01 M-p-chloromercuri- & 2 & $2-3$ \\
phenylsulphonate & & \\
\hline Bull LGP +53 Dx (0.1 mg/ml) & 2 & \\
\hline
\end{tabular}

Each experiment was carried out with three eggs which were incubated at $37^{\circ} \mathrm{C}$ and examined at 6 and $24 \mathrm{hr}$.

* See text.

Each experiment was carried out with three rabbit eggs: thus the results in the last column of Table 1 are each based upon the observation of at least six eggs. The final concentration of lipoglycoprotein was $3 \mathrm{mg}$ of protein $/ \mathrm{ml}$ in all cases. After eggs had been incubated in Ringer-saline or in Ringer-saline containing $0.01 \%$ Hyamine varying amounts of cumulus were still attached to the eggs (Pl. 1, Figs. 2 and 3). Experiments with the Ringer-saline-Hyamine medium serve as controls for all the following experiments in Table 1 since the residual Hyamine in the lipoglycoprotein preparations contributed not more than $0.01 \%$ of Hyamine to incubation media containing either ram or bull lipo- 
glycoprotein. Treatment with up to 1500 units $/ \mathrm{ml}$ of hyaluronidase did not remove the corona (Pl. 1, Fig. 4).

Ram, bull and rabbit lipoglycoproteins brought about extensive denudation of eggs (Pl. 1, Fig. 5) : cumulus and corona cells were invariably removed while the zona pellucida was removed in some instances and the vitellus attacked (Pl. 1, Fig. 6). After the lipoglycoproteins had been heated to $100^{\circ} \mathrm{C}$ their effects were limited to the cumulus layer. The two protein-binding reagents, iodoacetate and $p$-chloromercuriphenylsulphonate, had little or no effect upon the action of bull lipoglycoprotein but the former had a detectable, though variable, effect upon ram lipoglycoprotein. Iodoacetate $(0.067 \mathrm{~m})$ did not inhibit the activity of the commercial hyaluronidase preparation. The denuding activity of ram lipoglycoprotein, unlike that of bull lipoglycoprotein, was also sensitive to the hyaluronidase inhibitor 53DK. The two protein-binding reagents and 53DK each had no effect upon eggs in absence of lipoglycoprotein. Our preparations of acrosomal lipoglycoprotein from rabbit spermatozoa contained much non-acrosomal material. Of two such preparations one was active and removed the corona completely.

Substitution of acrosomal preparations by blood plasma glycoproteins A or B (see Materials and Methods) plus $0.01 \%$ Hyamine gave results which were indistinguishable from those of experiments with Ringer-saline-Hyamine. Incubation of eggs in Ringer-saline containing $1 \mathrm{~mm}$ concentrations of lactic, pyruvic or sialic acids gave virtually negative results: in some cases a partial removal of cumulus cells was observed.

ENZYME ACTIVITIES OF ACROSOMAL LIPOGLYCOPROTEINS

The hyaluronidase activity of ram lipoglycoprotein was $940 \mathrm{TRU} / \mathrm{mg}$ while that of bull lipoglycoprotein was 43 rRU/mg. The less pure acrosomal preparation from rabbit spermatozoa contained $35 \mathrm{TRU} / \mathrm{mg}$ of protein. Masaki \& Hartree (1962) found that when bull semen is stored at room temperature there is a transfer of hyaluronidase from the spermatozoa to the seminal plasma which is virtually complete in $6 \mathrm{hr}$. Under similar circumstances we have found that losses of hyaluronidase from ram spermatozoa are negligible. Thus with the latter species a valid comparison is possible between the level of hyaluronidase in spermatozoa and the level in the derived acrosomal lipoglycoprotein. In Table 2 the hyaluronidase activity of ram semen (i.e. of the spermatozoa in the semen) is derived from Hathaway \& Hartree's (1963) examination of the activity of extracts obtained by treating ram spermatozoa with cetyltrimethylammonium bromide. The activity of ram lipoglycoprotein is calculated from the yield of lipoglycoprotein: $480 \mathrm{mg} / 100 \mathrm{ml}$ of semen (Hartree \& Srivastava, 1965). Table 2 includes similar figures for bull semen but it must be remembered that a significant proportion of the hyaluronidase originally present in the bull spermatozoa had no doubt passed into the plasma before isolation of acrosomes could be carried out.

Proteolytic activities are given in Table 3. Ram lipoglycoproteins showed appreciable activity in water or in Ringer solution. In water, activity is enhanced by addition of albumen or by absence of oxygen. This lipoglycoprotein was inactive in phosphate buffer except when both oxygen and albumen were 
PLATE 1

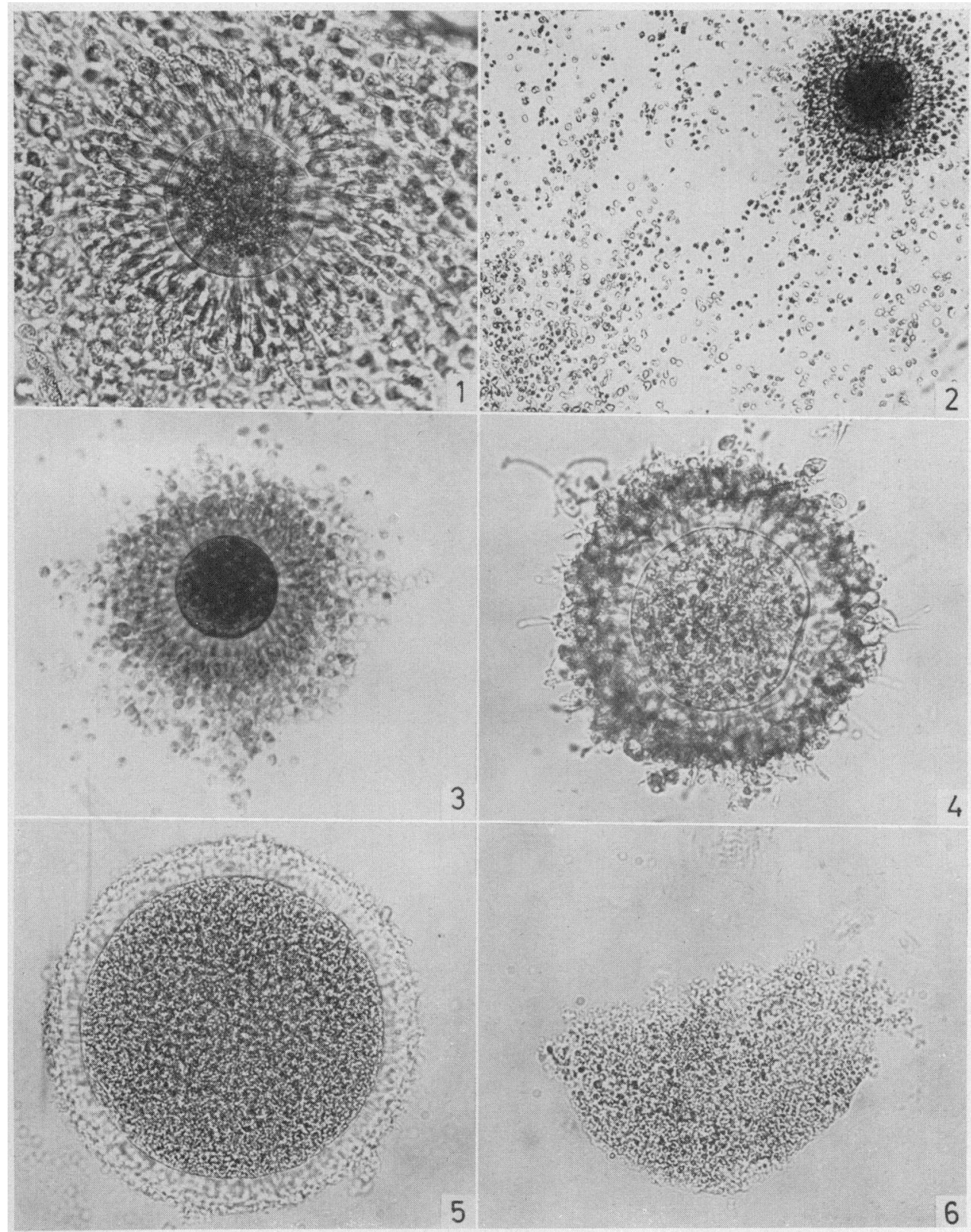

Fig. 1. Rabbit ovum, recovered shortly after ovulation, $13 \mathrm{hr}$ after LH injection $(\times 190)$.

Fig. 2. Rabbit ovum, after incubation in Ringer-saline for $24 \mathrm{hr}$ at $37^{\circ} \mathrm{C}(\times 75)$.

Fig. 3. Another rabbit ovum, treatment similar to that in Fig. $2(\times 120)$.

FIG. 4. Rabbit ovum treated with hyaluronidase, 1500 units $/ \mathrm{ml}$, for $6 \mathrm{hr}(\times 190)$.

Fig. 5. Rabbit ovum treated for $24 \mathrm{hr}$ with a rabbit acrosomal lipoglycoprotein preparation $(\times 300)$.

Fig. 6. Part of the vitellus of a rabbit ovum treated for $24 \mathrm{hr}$ wth ram acrosomal lipoglycoprotein $(\times 300)$.

(Facing p. 64) 
absent. Bull lipoglycoprotein showed some activity in air but this was largely abolished by the addition of albumen. These experiments suggest that the acrosomal preparation can catalyse the oxidation of amino acids. A similar enzymic oxidation of amino acids has been demonstrated in bull semen by Tosic \& Walton (1950). In one case albumen caused an initial lag in proteolysis and in others an inhibition throughout the experiments. Since albumen also

TABLE 2

HYALURONIDASE ACTIVITY, AS TURBIDITY REDUCING UNITS, OF SEMEN AND OF ACROSOMAL LIPOGLYCOPROTEINS

\begin{tabular}{|c|c|c|}
\hline & Ram & Bull \\
\hline Whole semen & $\nless 21,000 / \mathrm{ml}$ of semen* & 500 to $1000 / \mathrm{ml}$ of semen $\dagger$ \\
\hline $\begin{array}{l}\text { Lipoglycoprotein } \\
\text { (LGP) }\end{array}$ & $\begin{array}{l}940 / \mathrm{mg} \text { of LGP } \\
4500 / \mathrm{ml} \text { of semen }\end{array}$ & $\begin{array}{l}43 / \mathrm{mg} \text { of LGP } \\
\sim 70 / \mathrm{ml} \text { of semen }\end{array}$ \\
\hline
\end{tabular}

TABLE 3

PROTEOLYTIC AGTIVITY OF RAM AND BULL LIPOGLYCOPROTEINS (LGP)

\begin{tabular}{|c|c|c|c|c|c|c|c|c|c|c|c|}
\hline Solvent: & \multicolumn{4}{|c|}{ Water } & \multirow{2}{*}{\multicolumn{3}{|c|}{$\frac{\text { Ringer solution }}{\text { Air }}$}} & \multicolumn{4}{|c|}{0.06 м phosphate buffer, $p H 6.8$} \\
\hline Gas phase: & \multicolumn{3}{|c|}{ Air } & \multirow{2}{*}{$\begin{array}{c}\text { Nitrogen } \\
0.5\end{array}$} & & & & \multicolumn{2}{|c|}{ Air } & \multicolumn{2}{|c|}{ Nitrogen } \\
\hline $\begin{array}{l}\text { Time of } \\
\text { incubation }(h r)\end{array}$ & 1 & 2 & 3 & & 1 & 2 & 3 & 1 & 2 & 1 & 2 \\
\hline Ram LGP & $0 \cdot 23$ & $0 \cdot 31$ & $0 \cdot 43$ & $0 \cdot 38$ & 0.32 & 0.70 & $1 \cdot 21$ & 0 & -0.05 & 0.61 & 0.72 \\
\hline $\begin{array}{l}\text { albumen } \\
\text { Bull LGP }\end{array}$ & $\begin{array}{l}0 \cdot 38 \\
0 \cdot 25\end{array}$ & $\begin{array}{c}0.62 \\
(0.08)\end{array}$ & $\begin{array}{l}0 \cdot 70 \\
0 \cdot 33\end{array}$ & 0.58 & $\begin{array}{l}0.08 \\
\text { No } \mathrm{si} \\
\mathrm{ch}\end{array}$ & $\begin{array}{l}0.41 \\
\text { signific } \\
\text { hanges }\end{array}$ & $\begin{array}{l}0.74 \\
\text { cant } \\
\text { s }\end{array}$ & -0.06 & $-0 \cdot 20$ & 0.03 & -0.03 \\
\hline $\begin{array}{l}\text { Bull LGP + } \\
\text { albumen }\end{array}$ & $0 \cdot 04$ & 0.09 & -0.07 & & $\begin{array}{l}\text { No si } \\
\text { ch }\end{array}$ & $\begin{array}{l}\text { signific } \\
\text { hanges }\end{array}$ & $\begin{array}{l}\text { cant } \\
\text { s }\end{array}$ & & & & \\
\hline
\end{tabular}

Reaction mixtures contained LGP $(0.3$ to $1.2 \mathrm{mg}$ protein) and, where indicated, $100 \mu \mathrm{g}$ egg albumen in a total volume of $1.2 \mathrm{ml}$. Activities are expressed as changes in the content of free - $\mathrm{NH}_{2} \mathrm{groups}_{\text {, }}$ measured by a ninhydrin method (Yemm \& Cocking, 1955) against glycine standards, and expressed as $\mu$-equiv, of $-\mathrm{NH}_{2} / \mathrm{mg}$ of $\mathrm{LGP}$.

gave rise to increases in activity no interpretation of these effects can be suggested. Complete hydrolysis of $1 \mathrm{mg}$ of lipoglycoprotein would give rise to 6 to 8 $\mu$-equiv. of amino groups: therefore the observed proteolytic activities are rather low.

\section{DISGUSSION}

Our cell-free acrosomal lipoglycoprotein preparations from ram, bull and rabbit spermatozoa are able to disperse both cumulus and corona cells of rabbit eggs whereas the enzyme hyaluronidase only disperses the cumulus (Chang, 1950; Braden, 1952; Dickmann, 1962). The concentration of hyaluronidase in the 
bull preparation is much lower than that in the ram preparation yet they are equally effective as agents for dispersal of both cumulus and corona cells. It is clear, therefore, that some factor other than hyaluronidase is involved in the denuding activity of these lipoglycoproteins. Furthermore, while the hyaluronidase inhibitor 53DK partially blocked the activity of ram lipoglycoprotein it had no significant effect upon dispersal by bull lipoglycoprotein. However, clear interpretation of experiments with 53DK is made difficult by its lack of specificity as an inhibitor of hyaluronidase and by the fact that its inhibitory action can be reduced by addition of protein (Parkes et al., 1954). Our experiments support the views of Austin (1960) and Hathaway \& Hartree (1963) that at least part of the hyaluronidase of spermatozoa is present in, or associated with, the acrosome. Since the extent to which detergents can extract hyaluronidase from acrosomes is not known, the levels of hyaluronidase in acrosomes of intact ram and bull spermatozoa may well be higher than the values given in Table 2 for the corresponding lipoglycoproteins.

The absence of any denuding effect by two plasma glycoproteins and the lack of activity of boiled acrosomal lipoglycoproteins suggest that one or more specific enzymes are responsible for the denudation that we have observed. Steric factors may be responsible for the lack of inhibitory action of such a large molecule as $p$-chloromercuriphenylsulphonic acid. The negligible effects of lactic, pyruvic and sialic acids are consistent with the hypothesis of an enzymic mechanism. Sialic acid was tested since acrosomal preparations contain bound sialic acid (Hartree \& Srivastava, 1965) while the uterus of the rabbit contains neuraminidase, which liberates bound sialic acid, and an aldolase which converts sialic acid to pyruvic acid (Hartree \& Srivastava, unpublished results).

In vivo, physical factors, such as ciliary movement and muscular activity in the fallopian tube, undoubtedly contribute to the denudation of eggs (Swyer, 1947). However, in the experiments listed in Table 1 the eggs remained undisturbed and it is almost certainly for this reason that denudation occurred at a slower rate than in vivo and that periods up to $24 \mathrm{hr}$ were necessary for the full effect to be obtained. In the course of a few experiments in which tubes containing eggs were gently shaken, we did observe that denudation in the presence of either ram or bull lipoglycoprotein was considerably accelerated. In similarly treated controls the corona layer remained undisturbed. Denudation of rodent eggs, and also removal of the zona pellucida, can be brought about by different proteolytic enzymes (Yamane, 1930; Braden, 1952; Gwatkin, 1964; Edwards, 1964). Austin \& Bishop (1958) have postulated the existence of a 'zona lysin' which dissolves the zona pellucida of rodent eggs. Since in certain rodents the acrosome is detached before penetration of the zona occurs these authors suggested that the lysin originates in the perforatorium, a structure which they observed between the acrosome and the sperm head. Attempts to isolate from spermatozoa a proteolytic enzyme which will dissolve or disperse the hyaluronidase-resistant layers around the ovum have hitherto been unsuccessful (Austin, 1961). In some experiments with acrosomal lipoglycoproteins we observed removal of the zona pellucida. These lipoglycoproteins also showed proteolytic activity. It is possible that proteolytic activity lies not in the acrosome but in an adjacent structure, and proteolytic activity of the lipo- 
glycoproteins may be only a contaminant and therefore unrepresentative of the potential activity of spermatozoa.

Our investigations provide the first experimental evidence that proteolytic enzymes of spermatozoal origin contribute to the denudation of rabbit eggs and probably facilitate penetration of the zona pellucida.

\section{ACKNOWLEDGMENTS}

We wish to thank Dr H. J. Rogers, Dr K. Schmid, Dr J. L. Simkin and Bengers Ltd for gifts of materials, and Dr T. Mann, F.R.s., for his advice and encouragement. One of us (P.N.S.) is grateful to the Colombo Plan authorities for the award of a fellowship.

\section{REFERENCES}

Austis, C. R. (1960) Capacitation and the release of hyaluronidase from spermatozoa. F. Reprod. Fertil. $1,310$.

Austin, C. R. (1961) The mammalian egg. Blackwell Scientific Publications, Oxford.

Austin, C. R. \& Bishop, M. W. H. (1958) Role of rodent acrosome and perforatorium in fertilization. Proc. roy. Soc. B, 149, 241.

Braden, A. W. H. (1952) Properties of the membranes of rat and rabbit eggs. Austr. J. biol. Sci. 5, 460.

Chang, M. C. (1950) Fertilization, male infertility, and hyaluronidase. Ann. N.Y. Acad. Sci. 52, 1192.

Dickmann, Z. (1962) Studies on the rabbit egg, with special reference to denudation and sperm penetration. Ph.D. thesis, Cambridge University.

EDWARDS, R. G. (1964) Gleavage of one- and two-celled rabbit eggs in vitro after removal of the zona pellucida. 7. Reprod. Fertil. 7, 413.

Gwatkin, R. B. L. (1964) Effect of enzymes and acidity on the zona pellucida of the mouse egg before and after fertilization. 7. Reprod. Fertil. 7, 99.

Hartree, E. F. \& Srivastava, P. N. (1965) The chemical composition of the acrosomes of ram spermatozoa. F. Reprod. Fertil. 9, 47.

Hathaway, R. R. \& HARTREe, E. F. (1963) Observations on the mammalian acrosome: experimental removal of acrosomes from ram and bull spermatozoa. F. Reprod. Fertil. 5, 225.

Lowry, O. H., Rosebrough, N. J., FarR, A. L. \& Randall, R. J. (1951) Protein measurement with the Folin phenol reagent. $\mathcal{7}$. biol. Chem. 193, 265.

McGilean, D. \& Rowlands, I. W. (1942) Role of hyaluronidase in fertilization. Nature, Lond. 150, 627.

ManN, T. (1946) Studies on the metabolism of semen. 3. Fructose as a normal constituent of seminal plasma. Site of formation and function of fructose in semen. Biochem. 7. 40, 481.

MANN, T. (1964) Biochemistry of semen and of the male reproductive tract. Methuen, London.

MASAKI, J. \& HARTREe, E. F. (1962) Distribution of metabolic activity, phospholipid and hyaluronidase between heads and tails of bull spermatozoa. Biochem. 7. 84, 347.

Parkes, A. S., Rogers, H. J. \& Spensley, P. C. (1954) Biological and biochemical aspects of the prevention of fertilization by enzyme inhibitors. Proc. Soc. Study Fertil. 6, 65.

Pincus, G. (1930) Observations on the living eggs of the rabbit. Proc. roy. Soc. B, 107, 132.

Schmid, K. \& BURgI, W. (1961) Preparation and properties of the human Ba- $\alpha_{2}$-glycoproteins. Biochim. biophys. Acta, 47, 440.

Simkin, J. L., Skinner, E. R. \& Seshadri, H. S. (1964) Studies on an acidic glycoprotein-containing fraction isolated from guinea-pig serum. Biochem. 7. 90, 316.

SwYER, G. I. M. (1947) A tubal factor concerned in the denudation of rabbit ova. Nature, Lond. 159, 873.

TOLKSDORF, S. (1954) The in vitro determination of hyaluronidase. Methods of Biochemical Analysis, Vol. 1. Ed. D. Glick. Interscience, New York.

Tosic, J. \& Walton, A. (1950) Metabolism of spermatozoa. Formation and elimination of hydrogen peroxide by spermatozoa and effects on motility and survival. Biochem. 7. 47, 199.

YAMANE, J. (1930) The proteolytic action of mammalian spermatozoa and its bearing upon the second maturation division of ova. Cytologia, 1, 394.

Yемм, E. W. \& Cocking, E. C. (1955) The determination of amino-acids with ninhydrin. Analyst, 80, 209.

Zilliken, F., Braun, G. A. \& Györgyi, P. (1956) 'Gynaminic acid' and other naturally occurring forms of $\mathcal{N}$-acetylneuraminic acid. Arch. Biochem. Biophys. 63, 394. 